\title{
Evaluation for Production Efficiency of Methane from Anaerobic Digester Where Microbial Electrochemical Technology is Applied at Ambient Temperature
}

\author{
Wonbeom Shin, Heegyeong Ahn and Hangbae Jun ${ }^{\dagger}$ \\ Department of Environmental Engineering, Chungbuk National University, Cheongju, S. Korea
}

\begin{abstract}
Anaerobic digestion at low temperature is an innovative technology especially in ordinary temperature, however, low temperature results in low organic removal efficiency and low rates of methane production. This study investigated if agitating microbial methanogenesis cell (AMMC) can enhance methane production from highly concentrated food waste leachate in low-temperature anaerobic digestion (AD). AMMC reactor was operated with stainless steel agitator as anode and stainless steel reactor as cathode at ordinary temperature. Operational organic loading rate was $3 \mathrm{~kg} / \mathrm{m} 3 \mathrm{~d}$ and HRT was 20 days. For a comparison of efficiency, three control reactors (two conventional anaerobic digesters (at $35^{\circ} \mathrm{C}$ and Ordinary temperature) and one $A M M C$ reactor $\left(\right.$ at $\left.35^{\circ} \mathrm{C}\right)$ ) were operated with same reactor configuration.
\end{abstract}

Keywords: AMMC (Agitating Microbial Methenogenesis Cell), Ordinary temperature, Methane production, Stainless steel

\section{Backgrounds}

Anaerobic digestion is an attractive technology that recovers energy in the form of $\mathrm{CH} 4$, has low excess sludge production, and low operational cost (Speece, 2008). For anaerobic digestion, mesophilic conditions (25$37^{\circ} \mathrm{C}$ ) and thermophilic conditions $\left(55-65^{\circ} \mathrm{C}\right.$ ) are required to ensure optimal microbial activity (Hussain and Dubey, 2015). As low temperature leads to low activity and low growth rate of methanogens, and consequently to low $\mathrm{CH} 4$ production rate, strategies are needed to improve methanogenic activity of anaerobic sludge (Alvarez et al., 2004). The recent development of microbial electrochemical technology (MET), such as microbial electrolysis cells (MEC) and microbial methanogenesis cell (MMC), uses electrochemical reactions to produce biogas from anaerobic digester through a rapid degradation of highly concentrated organic wastes in low temperature. At current stage, however, the most likely limiting factors, large internal resistances, should be overcome for successful scale up of this technology. Various researchers reported that application of electrode materials containing high current density, increase of ion strength and conductivity, configuration of electrode are good methods for minimizing internal resistances. Recently, stainless steel is receiving great attention because of not only high performance and durability but also low cost. Therefore, in this study, we evaluate bioelectrochemical methane production using stainless steel agitating microbial methanogenesis cell (AMMC) in ordinary temperature.

\section{Materials and Methods}

In order to assess the effects of an AMMC on methane production in ordinary temperature, experiments were conducted in four continuous reactors. Two reactors were typical single agitating anaerobic digester, while the other reactors were a typical agitating single anaerobic digester that was combined with a microbial methanogenesis cell. Fig. 1 shows the configuration of reactors and electrodes. 


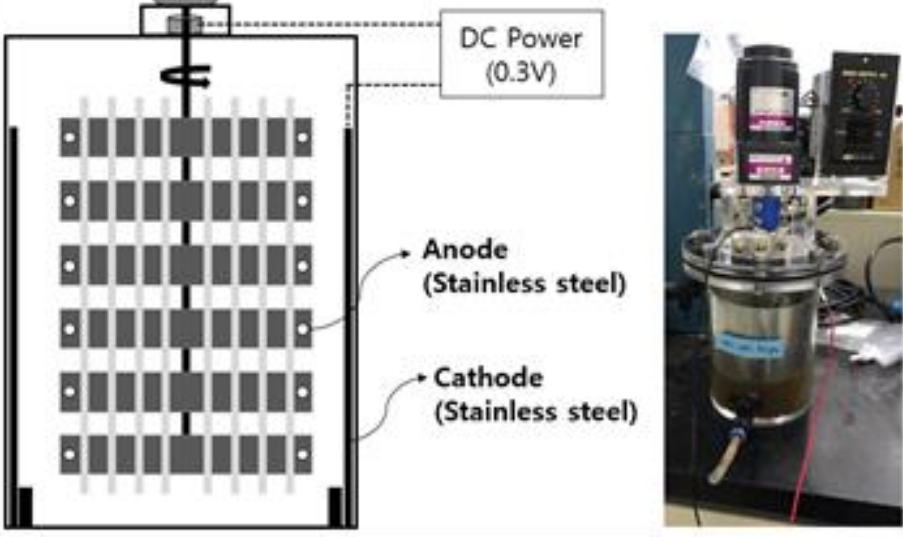

Fig:1 Configuration of the AMMC reactor.

An optimal voltage $(0.3 \mathrm{~V})$ to produce methane was provided (Feng et al., 2015). The organic load was 2.0 $\mathrm{kg}-\mathrm{COD} / \mathrm{m} 3 \cdot \mathrm{d}$ and each reactor was operated in a fed-batch method, whereby it was provided and discharged once daily at ordinary temperature and $35^{\circ} \mathrm{C}$ (Table 1$)$.

TABLE I. Operational conditions of each reactors.

\begin{tabular}{|c|c|c|c|c|}
\hline Parameters & Control 1 & AMMC 1 & Control 2 & AMMC 2 \\
\hline Voltage & - & $0.3 \mathrm{~V}$ & - & $0.3 \mathrm{~V}$ \\
\hline Temperature & \multicolumn{4}{|c|}{$10-20^{\circ} \mathrm{C}$} \\
\hline Substrate & \multicolumn{4}{|c|}{ Food waste leachate $\left(3.0 \mathrm{~kg}-\mathrm{COD} / \mathrm{m}^{3} \cdot \mathrm{d}\right)$} \\
\hline HRT & \multicolumn{4}{|c|}{20 days } \\
\hline
\end{tabular}

\section{Results and Discussions}

Results of this study will be attached.

\section{References}

[1] Speece, R.E., 2008. Anaerobic Biotechnology and Odor/corrosion Control for Municipalities and Industries. Incorporated. Fields Publishing.

[2] Alvarez, J.A., Armstrong, E., Presas, J., G_omez, M., Soto, 2004. Performance of a UASB-digester system treating domestic wastewater. Environ. Technol. 25(10), 1189-1199.

https://doi.org/10.1080/09593332508618386

[3] Hussain, A., Dubey, S.K., 2015. Specific methanogenic activity test for anaerobic degradation of influents. Appl. Water Sci. 1-8.

[4] Wonbeom Shin is with the Department of Environmental Engineering, Chungbuk National University, Cheongju, S.Korea(corresponding author's phone:+82-43-261-2470 ; e-mail:shin_9168@ naver.com).

[5] Heegyeong Ahn is with the Department of Environmental Engineering, Chungbuk National University, Cheongju, S.Korea(corresponding author’s phone:+82-43-261-2470 ; e-mail:heegyung52@ naver.com).

[6] Hangbae Jun is with the Department of Environmental Engineering, Chungbuk National University, Cheongju, S.Korea(corresponding author’s phone:+82-43-261-2470 ; e-mail:jhbcbe@cbnu.ac.kr). 